\title{
SALONES, BAILES Y CAFÉS: COSTUMBRES SOCIO-MUSICALES EN EL MADRID DE LA REINA CASTIZA (1833-1868)
}

\author{
M. ${ }^{a}$ Aurelia DíEz HuERgA
}

\section{Resumen}

En el siglo XIX arranca el fenómeno asociativo, no sólo en los ámbitos político y laboral sino también en el recreativo-cultural, lo cual afectará a la expresión artística y, de manera especial, a la música, ya que surgirá un gran número de sociedades (inicialmente en Madrid y con posterioridad en las provincias) con vocación de auspiciar, promover y difundir actividades musicales desde una triple perspectiva: pedagógica, creativa e interpretativa.

Estamos, parece ser, ante un momento de nuestra historia especialmente proclive al asociacionismo, de manera significativa durante el reinado isabelino, si bien es cierto que la sociabilidad de los españoles no se agota en estas manifestaciones de carácter organizado sino que busca otras vías de expresión más espontánea e informal.

El presente trabajo pretende hacer una reflexión acerca de salones privados, bailes públicos y cafés con música en el Madrid de Isabel II. En unos y otros, cada uno a su modo y con sus particularidades, la presencia de la música adquirió importancia de primer orden, cauce para satisfacer las necesidades disipativas, artísticas y de sociabilidad de todas las clases sociales en las décadas centrales del XIX.

\begin{abstract}
The associative phenomenon sets off in the nineteenth century, not only within the limits of politics and labour but also of culture and entertainment, which will have an effect on artistic expression and, especially, on music, as many societies will spring up with a vocation for sponsoring, promoting and divulging musical activities in a triple perspective: pedagogic, creative and interpretative.

We seem to be facing a moment of our history which is particularly inclined to recreational and cultural partnership, meaningfully during the reign of Isabel II, even though Spanish people's conviviality doesn't finish with these organised signs but also searches other ways of expression, more informal and spontaneous.

The present essay intends to think over private assembly rooms, public balls and cafés which provided entertainment in Madrid during Isabel II's era. In both cases, each one its way and with its special features, music became of great importance and a course to satisfy the social, artistic and recreational necessities of all classes during the middle decades of XIX century.
\end{abstract}

El período isabelino trajo consigo el esplendor del fenómeno asociativo cultural. Las principales sociedades de ámbito burgués con implicaciones musicales nacen al poco de iniciarse el reinado de Isabel II, apodada la reina castiza, y muchas otras que también conocerán su declive en época de dicha soberana e, incluso, darán pábulo al surgimiento de nuevas sociedades en décadas posteriores. Parece evidente que los habitantes del Madrid decimonónico manifiestan una especial tendencia al colectivismo de índole diversa. Si bien es cierto que el asociacionismo organizado cobra especial pujanza en estos años, la reflexión acerca de la vida socio-musical madrileña quedaría incompleta si nos limitára- 
mos al marco puramente formal u organizado, ya que, de modo paralelo a éste, continúan las manifestaciones colectivas de naturaleza más espontánea e informal que en décadas anteriores habían proporcionado solaz a los ciudadanos de la capital, cuando aún no existían aquellas entidades instructo-recreativas. Hablamos de salones privados, bailes y cafés cantantes, que, lejos de venir a menos, manifiestan notoria activación, en sintonía con una época de intensificación cultural.

En línea con la costumbre del período fernandino, por entonces ya consolidada entre la nobleza, asistimos al florecimiento de veladas, tertulias, reuniones, tés o soirées -como ahora se las llama-, de carácter privado, en residencias aristocráticas y domicilios burgueses. Si bien el objeto de las reuniones es básicamente el mismo, se aprecia una considerable evolución en los sustratos sociales que las regentan, consecuencia de los cambios socio-económicos de los años treinta.

Los salones nobiliarios -según el testimonio del Marqués de Mendigorría, quien tenía acceso a ellos como oficial del ejército- parecen manifestar cierto debilitamiento, al menos en algunas de sus actividades, con relación a la época previa: "por circunstancias ya expuestas que fueron consecuencia de la guerra, la sociedad de Madrid había perdido aquel brillo incomparable y aquel fasto de que dio muestra en los últimos años del reinado de Fernando VII, cambiando mucho de aspecto, como cambian las naciones mismas por los hechos políticos trascendentales. De aquellas fiestas brillantísimas de la corte, de aquellos bailes espléndidos y de las grandes casas españolas, no quedaba ya sino el recuerdo, junto con el pesar de que no pudieran reproducirse. Williers, el ilustre diplomático de que tanto he hablado, era el único que de cuando en cuando recibía a toda la sociedad madrileña en sus salones"'. Sin embargo, lo que añade a continuación hace frente a ese aparente languidecimiento de las veladas de la alta sociedad:

"Pero, en cambio, habían prosperado las tertulias, hijas de aquella transformación y notoria necesidad para que las relaciones íntimas sociales no quedaran totalmente interrumpidas. Las mejores familias de Madrid recibían diariamente a sus parientes y amigos de confianza, y como el parentesco y la amistad se extienden tanto en nuestras clases elevadas por constantes enlaces, era seguro hallar en las tertulias a todo Madrid si se frecuentaban las principales. De tal modo establecidas eran estas reuniones agradabilísimas y en opinión de muchos y en la mía, más gratas que los grandes bailes, por muchas razones que sabrán apreciar los que las hayan conocido".

En la mayoría de los salones, las tertulias cotidianas suceden a las recepciones fastuosas. Se deduce, pues, que lo que la aristocracia madrileña -el "todo Madrid" hace referencia a lo más selecto de la sociedad- había perdido en 1836 era el boato de años atrás, no su actividad. De hecho, el marqués prosigue su narración con un breve "paseo" por los salones más célebres, los más concurridos a la sazón y donde él y sus amigos se dejaban ver a veces en una misma noche, pues "era entonces muy elegante recorrer medio Madrid cada noche y entrar en seis o siete salones": el de la marquesa de Santa Cruz, respecto al cual "el Cuerpo diplomático extranjero, los jefes y alta servidumbre de Palacio; los grandes de España y los hombres más eminentes del país disputábanse sus preferencias"². La casa de Oñate "era

1. Fernández de Córdova, Fernando, Mis memorias íntimas. Madrid, Establecimiento tipográfico "Sucesores de Rivadeneyra”, 1886. Edición consultada: Madrid, Atlas, 1966, pp. 299-303.

2. Ibídem nota anterior. 
también de mucho fuste, aunque recibía menos gente que la de Santa Cruz, eran allí admitidos diariamente las amigas y amigos íntimos"3. El periplo continuaba en la tertulia del duque de Ahumada, a la que acudían los militares con cierta frecuencia, o en casa de Ezpeleta, donde se veía casi de continuo a "la marquesa de Campo Verde, a la de Villacampo, a la condesa de Vilches y su hermana Matilde, y a la marquesa de San Felices" . No hemos de olvidar la casa de la marquesa viuda de Perales ni la del noble conde de Puñonrostro, donde "concurrían frecuentemente Martínez de la Rosa, Frías, el duque de San Lorenzo, Toreno, Alava, Valdés, Ofelia, Almodóvar, Someruelos" y muchas otras personalidades de la política, junto a señoras muy asiduas como "la Santa Coloma, la duquesa de Tamames, la Guendulain y su hija, la ilustre marquesa de Besoya, la baronesa de Bigüezal y su hermana"5.

En aquellas veladas la política solía estar presente como tema de conversación, junto a las noticias de la guerra y cotilleos relacionados con algún matrimonio proyectado o la ruptura de ciertos novios conocidos, pues, continúa Fernández de Córdova en sus memorias, "no se hubieran consentido entonces, como tengo entendido se toleran ahora, otra suerte de noticias chismográficas de color subido y acompañadas de comentarios, que en aquella época se reservaban para las reuniones de hombres solos".

Además de charlar, se jugaba a las cartas. Parece ser que el juego fue un pasatiempo de general aceptación y presencia en las tertulias -con sus excepciones-, sobre todo entre las personas mayores. "Claro es que no faltaban en ellas las indispensables mesas de tresillo; pero se relegaban al gabinete de las personas graves, porque en aquella época no atraía ni mucho menos esta soñolienta distracción a las damas jóvenes ni a las señoritas, según me dicen que acontece en el día. Algunos personajes mayores dedicábanse también con una gran constancia y solemnidad a los juegos de paciencia u otras suertes de baraja"6. Sin embargo, este entretenimiento no se daba en algunas casas, como las de la marquesa de Santa Cruz y el conde de Puñonrostro, donde "no se jugaba ni al tresillo ni a nada"7. No obstante las excepciones, los juegos de naipes y otros muchos gozaron de gran aceptación, también en los círculos burgueses y populares. Prueba de ello son las numerosas publicaciones al respecto que circulan por aquellos años ${ }^{8}$.

También la música hacía acto de presencia en las reuniones, aunque no en todas, frecuentemente de manos de las señoritas y amigas de la casa. "Lo más agradable en aquellas casas era siempre el salón de la gente joven, donde como era natural no faltaban tampoco las madres y señoras de respeto. Dedicábanse las muchachas ordinariamente a labores propias de su sexo, y en algunas, aunque no en muchas casas, a la música"9. De hecho, la aptitud para cantar o interpretar piezas instrumentales era

\footnotetext{
3. Ibídem.

4. Ibídem.

5. Ibídem.

6. Ibídem.

7. Ibídem.
}

8. Se trata de obras que contienen variedad de juegos en boga por aquel entonces y la explicación de sus reglas. Algunos eran traducciones de autores franceses (expresión una vez más de las modas extranjeras), como Madame Celnart y su Manual completo de juegos de Sociedad o Tertulia y de Prendas, el cual "contiene una colección de los juegos de campo y de casa, la descripción de las montañas rusas y otras varias; juegos preparados de prendas, de chasco, de acción, charadas representadas, juegos de memoria, de ingenio, de palabras y penitencias concernientes a cada una de ellos y modo de sentenciar las prendas, con Diferentes juegos de Niños y de Naipes", vertido al español por vez primera en 1839.

9. Ibídem, nota 1. 
considerada un aderezo imprescindible para las señoritas, que solían exhibir sus dotes interpretativas en aquellas veladas. La música adquiere importancia como elemento socializador y de proyección personal -con sus derivaciones matrimoniales-, como medio de ostentar la buena educación, sobre todo en el sexo femenino.

Adeline Daumard ha estudiado el fenómeno sociológico que supuso el florecimiento de los salones en la Francia decimonónica, de manera especial durante la primera mitad de siglo, del cual muchos aspectos son extrapolables al caso español, cuyos círculos burgueses y aristocráticos manifiestan una clara impronta de sus homólogos en suelo vecino. Las aportaciones de esta autora son especialmente interesantes en lo relativo a la función ejercida por la mujer en la actividad de los salones, en la medida en que plantea un estudio bidireccional de una cuestión sobre la que se han hecho escasas reflexiones hasta la fecha: el papel femenino en el marco del salón octocentista y, cambiando el orden de los términos, el significado que la vida de salón adquirió para las mujeres que tenían acceso a aquellos espacios. En relación con el primer punto hay que recordar la importancia que algunas mujeres tuvieron en materia de política, literatura o arte, así como en la difusión e imposición de gustos o ideas en su época, como sucedió con damas distinguidas de los círculos nobiliarios y altoburgueses, cuyos maridos detentaron cargos relevantes en las esferas política y económica. Se dice, y esto quizá sea un tópico, que muchas de aquellas esposas fueron piezas clave en la toma de decisiones trascendentes, ensombreciendo incluso la figura de sus propios maridos. Sin duda, a juicio de Daumard, hay una parte significativa de leyenda en el rôle atribuido a estos personajes, puesto que las mujeres, por sí solas, no tenían el poder para construir la carrera de los varones a los que distinguían, ni tampoco la capacidad para decidir en los asuntos públicos. Por otra parte, añade la autora, no hay que minusvalorar la intervención masculina en unos espacios frecuentados por ambos géneros ${ }^{10}$. No obstante, es innegable que hay parte de verdad en ello, según expone Melchor Almagro en su retrato de la sociabilidad decimonónica de alto copete y, de un modo más concreto, en su alusión al salón de la marquesa de Squilache, figura centrípeta en la actividad social aristocrática del Madrid de finales de siglo:

“A través de todo el período contemporáneo, y aún antes, influyó el salón, trono de la mujer, en la vida española, no tanto quizás como en Francia, pero de tal suerte, sin embargo, que más de una crisis, alguna grave decisión estatal, una orientación en la política hispana, hallaron su génesis cabe los techos pintados con ángeles y diosas, donde la frivolidad aparente encubría bajo polvos de arroz, lunares postizos y falsos carmines, la intriga o la conspiración (...). Centro y signo de la vida madrileña durante la Regencia y casi todo el reinado de Alfonso XIII fué la marquesa de Squilache, dama de rara sagacidad, que supo, poco a poco, contra viento y marea, llegar al puesto social que se propuso, influyendo de paso notablemente en la política de su tiempo, que es notorio gobiernan las hembras por su dominio sobre los hombres, cuando ellas no tienen directo acceso a los empleos públicos" ${ }^{11}$.

El segundo punto ofrece, quizá, menos dudas. El salón se convirtió en un espacio sustancial, imprescindible, si se quiere, en la vida de muchas mujeres del XIX. Nos referimos, naturalmente, a las

10. Daumard, Adeline. "La vie de salon en France dans la premiére moitié du XIX siècle ". Sociabilité et societé bourgeoise en France, en Allemagne et en Suisse, 1750-1850. Paris, Recherche sur les Civilisations, 1986.

11. Almagro San Martín, Melchor, Bajo los tres últimos Borbones. Retratos, cuadros e intimidades. Madrid, Imp. Afrodisio Aguado, 1920, pp. 87-88. 
de clase alta o acomodada, cuya holgada posición las liberaba de las fastidiosas tareas del hogar -confiadas al servicio doméstico- o de la necesidad de trabajar para completar los ingresos del esposo, cosa habitual en los medios populares. En contrapartida, esa holganza las abocaba al más insoportable de los tedios, debiendo buscar un medio para ocupar las horas libres de funciones familiares, sin duda muy numerosas. Es aquí donde entra en escena la vida de salón, no sólo como entretenimiento para las damas ociosas, sino como medio de realización, por así decir, para muchas de ellas, ansiosas por alcanzar protagonismo y reconocimiento en la buena sociedad. "Les jeunes femmes qui menaient une vie mondaine trouvaient un dérivatif dans les hommages qui se portaient vers elles: elles régnaient, ou croyaient régner, par leur beauté ou par leurs charmes et, à quelques exceptions près, cela suffisait à les satisfaire. Plus âgées, elles cherchaient une raison d'être en organisant un salon (...). Chez elles, elles étaient souvaraines, libres d'accuueillir ou de remeter les hôtes de leer choix, d'imposer ce que'elles considéraient comme les bons usages, de faire ou de défaire des réputations"12.

Por otro lado, la reunión de sociedad constituye un trámite de obligado cumplimiento para aquéllas que desean entrar en determinados círculos sociales, de manera especial las jóvenes. Las muchachas casaderas tenían en el salón la oportunidad de conocer y ser conocidas, como espacio privilegiado que era para la concertación de matrimonios convenientes, hecho constatable ya en el XVIII, con la diferencia de que mientras en aquella época la jovencita no tenía ni voz ni voto en un pacto establecido por sus familiares, la nueva sensibilidad del siglo XIX va introduciendo el hábito de consultar el parecer de la muchacha. El salón decimonónico es escenario de encuentros entre ambos géneros menos esporádicos o superficiales que en la centuria anterior, brindando la oportunidad para un conocimiento mutuo más profundo y sedimentado. "Grâce à la vie de salon (apunta Daumard) la jeune fille n'était plus seulement un pion dans une stratégie d'intérêts et d'influence familiale, sa personalité commencait à être prise en compte, c'était un pas vers une égalité morale entre les hommes et les femmes"13. Pero el éxito no estaba garantizado con un buen casamiento. Había que perseverar, medrar en las relaciones para hacerse un hueco en el entorno social, tarea insoslayable para las recién casadas, a quienes, continúa la autora, "l'usage leur imposait de faire des visites de noce au tours desquelles il leur fallait gagner l'estime de censeurs sévères, avant d'être vraiment admises dans la socièté où elles se trouvaient placées après leur mariage et, à cet ègard, les salons de la bourgeoisie, fût-elle modeste par ses fonctions et ses ressources, n'étaient pas moins absolus dans leurs apprèciations que ceux de l'aristocratie riche et influente"14.

A decir verdad, la comparecencia en las reuniones de sociedad constituía una prueba que debían afrontar los debutantes de ambos géneros. Podría decirse que de su destreza en las primeras "apariciones públicas” dependía su trayectoria posterior. Así pues, el salón decimonónico desempeñó un papel deter-

12. "Las jóvenes que llevaban una vida mundana hallaban un derivativo en los homenajes que se les dirigían: ellas reinaban, o creían reinar, por su belleza o por sus encantos y, con alguna excepción, esto era suficiente para satisfacerlas. Una vez alcanzada la edad madura, buscaban una razón de ser al organizar un salón (...). En su casa, ellas eran las soberanas, libres para acoger o rechazar a los invitados según su voluntad, para imponer lo que ellas consideraban como buenas costumbres, para hacer o destruir reputaciones". Daumard, A. "La vie de salon en France..., p. 89.

13. "Gracias a la vida de salón, la muchacha dejó de ser un peón en una estrategia de interés e influencia familiar, su personalidad comenzó a ser tenida en cuenta, fue un paso hacia la igualdad moral entre varones y mujeres". Ibídem, p. 90.

14. "el uso obligaba a realizar visitas durante las cuales era imprescindible ganarse la estima de severos censores antes de ser verdaderamente admitidas en la sociedad donde habían sido ubicadas tras su matrimonio y, a este respecto, los salones de la burguesía, aunque fuese modesta por sus funciones y sus recursos, no eran menos contundentes en sus apreciaciones que los de la aristocracia rica e influyente". Ibídem, p. 89. 
minante en la vida profesional y afectiva de los concurrentes. De esa función "mediática", por así decir, para la consecución de unos fines, se deriva un espacio dominado por las apariencias y la adulación. La reflexión introducida por Julio Nombela en su remembranza de relaciones trabadas en círculos burgueses y experiencias vividas a mediados de siglo lamenta la artificialidad en el papel interpretado por las damas en los salones isabelinos, lo cual no deja de ser tan sólo un elemento de la "comedia social" en la que varones y mujeres se ven involucrados, siendo reflejo de una fachada, una gran "feria de las vanidades" que conviene conocer al que se adentra en aquellos espacios en busca de autenticidad:

"Por intuición, y también por la experiencia adquirida, había llegado a convencerme de que el trato social contribuía a desarrollar en las jóvenes más defectos que virtudes. Aquellas especiales amigas mías, que no vacilaban en confiar a mi lealtad las flaquezas que producían en su ánimo las heridas que sufrían su amor propio, su vanidad y a veces su envidia, las ideas de inconsciente ambición que bullían en aquellas hermosas cabezas me estimularon a pensar que la mayoría de las señoritas que por la próspera y a veces brillante posición de su familia frecuentaban la sociedad, aunque inspiradas por la más completa moralidad y cumpliendo, quizá más por costumbre que por verdadero e íntimo sentimiento, las prácticas religiosas, prestaban a las exterioridades de la vida mayor importancia que a los afectos que al desarrollarse en el misterio del hogar pueden ofrecer las dichas posibles en el mundo. Todo para la flor, poco o nada para la raíz.

Aun aquéllas en quienes había reconocido y admirado cualidades excepcionales, nacidas y criadas en el seno de familias ricas y de brillante posición, no podían prescindir, reinas de la belleza y de la fortuna, de la atmósfera artificial, falsa y lisonjera con que la cortesanía envuelve a los soberanos, oscureciendo con el oropel el oro fino de sus naturales sentimientos.

Así es que cuando pensaba en que algún día tendría que elegir la compañera de mi vida, me decía: 'no la buscaré en los salones, en los teatros ni en los paseos. Procuraré que la perla esté todavía en su concha, que sea de condición humilde y hasta pobre como yo, pero con un alma privilegiada que me inspire el deseo de trabajar y vivir exclusivamente para labrar su felicidad", 15 .

En otro orden de cosas, hemos de apuntar asimismo que, aparte de constituirse en espacio idóneo para la toma de decisiones políticas o profesionales -pues aquellos encuentros distendidos permitían habitualmente abordar cuestiones de tal índole con más facilidad y rapidez que las propias convocatorias oficiales-, el salón constituyó un medio primordial para la difusión cultural. Los asistentes hallaban en la conversación la forma de completar su instrucción de forma agradable y sin esfuerzo, pudiendo adquirir un conocimiento superficial, aunque suficiente como cultura general, en materias diversas. Asimismo, aquellas veladas fueron cauce para la propalación de corrientes novedosas en los ámbitos artístico y literario, ya que, según Daumard, "les rencontres et les conversations de salon ont contribuí à diffuser les idèes et les sentiments qui font la modernité du XIX siècle (...). Les salons ont agi comme un écho pour amplifier ce que aurait pu être ignoré ou negligé sans les contacts qu'ils permettaient d'établir" ${ }^{\prime 6}$. En realidad, eran consumidores de lo que ellos mismos imponían, pues seguían las modas en la misma medida en que las inspiraban.

15. Nombela, Julio. Impresiones y recuerdos. Edición consultada: Madrid, Tebas, 1976, p. 519.

16. "las reuniones y las conversaciones de salón contribuyeron a difundir las ideas y sentimientos que conforman la modernidad del siglo XIX (...). Los salones actuaron como un eco para amplificar lo que habría podido ser ignorado o descuidado sin los contactos que ellos permitieron establecer". Daumard, A. "La vie de salon..., p. 91. 
Durante la primera etapa de la monarquía isabelina -parte de los años cuarenta y cincuenta, tiempos de moderantismo que coinciden con cierta estabilidad política y económica-, los salones nobiliarios se rodean de esplendor, recibiendo notorio impulso la actividad filarmónica en ellos, cosa que perdurará ya hasta finales de siglo. Los reyes asisten a conciertos en palacio, coincidiendo con fiestas solemnes, en los que intervienen incluso las personas reales como intérpretes:

"El lunes ha tenido lugar en uno de los salones del Real palacio un concierto de familia, que puede decirse ha sido el mas brillante de los de esta clase. El objeto principal de esta fiesta era oir las siete palabras del célebre Haydn ejecutadas por SS. MM. y A. y otras Varias personas, según habia manifestado desearlo la augusta Reina madre. En efecto, esta gran composición fue ejecutada bajo la direccion del digno maestro de las personas reales, D. Francisco Valldemosa, siendo admirable la perfeccion é inteligencia con que desempeñaron las respectivas partes S. M. la Reina y sus augustas madre y hermana, no habiendo dejado tampoco nada que desear en la ejecución de las que se habian encargado á la señorita Campuzano y los señores duque de Rianzares, Siguer, Calvo y Reguer. El acompañamiento estuvo á cargo del cuarteto de profesores de la Real capilla.

Cantáronse ademas otras piezas en que manifestaron su buen gusto las reales personas. La reina doña Isabel, dijo muy bien un duo de Il Giuramento, con la señorita Campuzano. El serenisimo señor infante don Francisco cantó con el señor Reguer el duo de bajos de los Puritanos, y S. M. la Reina cantó ótro duo de la Estranjera con el señor Siguer.

Tambien lucieron su habilidad S. M. y su augusta hermana en la ejecución al piano de dos fantasias nuevas compuestas por su digno maestro el señor D. Pedro Allbeniz. Estas piezas agradaron estraordinariamente á la brillante concurrencia que habia recibido la honra de asistir á esta régia funcion" ${ }^{17}$.

La iniciativa es prontamente emulada por familias de rancio abolengo. Tal es el caso de "los conciertos y bailes del marqués de Miraflores. La condesa de Montijo abrió un salón los domingos en el palacio de la plaza del Angel, uno de los más selectos hacia 1850, con una actividad musical infatigable". De primera fila eran "los salones madrileños de los marqueses de Valparaíso, marqueses de San Carlos, la baronesa Emilia (uno de los mejores hacia 1845, trasunto de las reuniones del Liceo y el Instituto), la condesa de Campo Alange, duquesa de Medinaceli (con una importante tertulia literaria), marqueses de Canga Argüelles, duquesa de Bara, condesa de Laguna y marqués de la Estepa”. Más tarde, tras un paréntesis durante el Bienio Progresista, prosiguen las reuniones filarmónicas. "Recibían semanalmente la casa de Osma, Narváez, Weisweiller, el conde de Galen y el marqués de Turgot (embajador de Francia). Eran famosos los saraos de los Malpica, los Duques de Sotomayor, los condes de Velle, de Superunda y el marqués de Villavieja"18.

Con los acontecimientos revolucionarios y la inestabilidad política del Sexenio disminuyen la frecuencia y el boato en los salones nobiliarios, tendentes a desarrollar su actividad en veladas de carácter más íntimo, en las que la política era tema de ordinaria discusión entre los partidarios de las diversas alternativas al poder. Por aquellos años abrían sus puertas las casas de Alba, Medinaceli, Montijo, Sexto, Alcañices, Portugalete, Miraflores, Santa Cruz, Rivas, Bedmar, Perales o Superunda, a cuyas veladas asistían políticos, diplomáticos, renombrados hombres de las letras y de las artes.

17. “Correo de Madrid”. La Iberia Musical. Gaceta de Teatros, año V, n. ${ }^{\circ}$ 15. Madrid (19-IV-1846), p. 123.

18. Alonso, Celsa, La Canción Lírica Española en el siglo XIX. Madrid, ICCMU-SGAE, 1998, pp. 193 y ss.

19. Ibídem, p. 379. 
La llegada de la Restauración monárquica en la persona de Alfonso XII produce ese mismo efecto en la actividad social nobiliaria -sin duda influenciada por la estabilidad política alcanzada con el nuevo régimen-, recuperándose el fasto de los años isabelinos, materializado en recepciones, cotillones, conciertos, veladas literarias o artísticas y esplendorosos bailes. Sin embargo, el fallecimiento del monarca diez años después y la asunción de la regencia subsiguiente por parte de su segunda consorte, M. ${ }^{a}$ Cristina de Austria, cuya seriedad afectó sustancialmente a las costumbres de palacio, generando una atmósfera de austeridad y comedimiento, minaron el clima jovial y distendido que se había generalizado en vida del rey. Celsa Alonso cita los más notorios salones que, de manera excepcional, se mantienen en activo, baluartes de la vida social aristocrática del Madrid finisecular: los de las marquesas de La Laguna, Squilache, Ivanrey, los del duque de Bailén y los marqueses de Hoyos, Cerralbo, así como el de los condes de Guaqui, todos ellos con una actividad en la línea de las décadas previas ${ }^{19}$. El marqués de Lema nos refiere en sus memorias los salones que despuntaban entre los años 1885 y 1900, aludiendo a las tertulias del marqués de La Habana, la marquesa de Squilache, la marquesa viuda de la Torrecilla, la condesa de Villagonzalo, los duques de Alba, la casa de Fernán-Núñez, la duquesa viuda de Medinaceli y la señora de Buschental20.

Pero no sólo la vieja nobleza se daba cita en tales espacios. Miembros de la alta burguesía, los "nuevos ricos" -también aludidos como la "nobleza del dinero"- se codean ahora con las gentes de alcurnia, en un alarde de grandeza. Para comprender la situación habremos de remontarnos a los comienzos del orden liberal, en la década de los treinta. La nueva coyuntura político-económica del país tras el período fernandino (el liberalismo económico, traducido en la abolición de los gremios, que aseguraba la libertad de trabajo y permitía una reactivación del comercio y de la industria; la venta de las propiedades eclesiásticas y la supresión de los mayorazgos, entre otras) favorece el ascenso de familias de empresarios y comerciantes, quienes saben aprovechar las oportunidades financieras que les brinda el momento. Durante los años de guerra, y acuciados por la necesidad de dinero, tanto el propio Estado como la declinante aristocracia recurren a ellos solicitando préstamos o provisiones. Santos Juliá explica con claridad lo que significó la oportunidad "de oro" para un sector burgués cuyos miembros serán catapultados a puestos de poder en el nuevo sistema, hasta entonces reservados a la clase privilegiada: "acudieron en su socorro ayudando a sanear los patrimonios nobiliarios $-\mathrm{y}$ transfiriendo al suyo parte de sus posesiones inmobiliarias cuando los nobles renegociaban su deuda- y comprando las fincas que el estado, acuciado por sus necesidades hacendísticas más que guiado por algún propósito revolucionario, arrebataba a frailes y curas, o actuando como aprovisionadores de armas, de ropa, a las tropas que el gobierno enviaba para combatir la deslealtad carlista. Luego, ya no hubo remedio: esa nueva grandeza, ligada inextricablemente con el Estado, convirtió a Madrid en capital de las finanzas y se convirtió ella misma en proveedora de dinero" 21 . De este modo, la conquista del poder económico les abre las puertas del poder político. Familias de capitalistas, principalmente banqueros y comerciantes, como los Caballero, Urquijo, Murga, Rivas, Chavarri, Norzagaray, Peréz Seoane,

20. Bermúdez de Castro y O’LaWlor, Salvador (marqués de Lema), Mis recuerdos (1880-1901). Edición consultada: Madrid, Compañía Ibero-Americana de Publicaciones, 1930, pp. 78-79.

21. Juliá, Santos; Ringrose, David; Segura, Cristina, Madrid. Historia de una capital. Madrid, Alianza, 1994, p. 72.

22. MARRASt, Robert, José de Espronceda y su tiempo. Barcelona, Crítica, 1989, p. 570. 
Fagoaga, Remisa y otras logran abrirse un hueco entre las más linajudas del país. Esta alta burguesía, prosigue Juliá, "al acercarse tanto a la corona y tocar con sus manos el poder político, pasó primero a frecuentar los paseos aristocráticos y se atrevió después a entrar en los salones nobiliarios, abiertos ahora también a ella porque en ella era ya sociedad. No le costó nada, una vez admitida en sociedad, convertirse en nobleza, acopiando títulos que una corona pródiga más que generosa en la cooptación nobiliaria no escatimaba a los triunfadores del agiotismo y la especulación. Serán el núcleo permanente de la nueva oligarquía, moderada o progresista con irrefrenable tendencia a la moderación, los protagonistas de la vida social madrileña que los duques, condes y marqueses de viejo tronco deberán aceptar a su lado, como prestamistas primero, como parientes después".

Esta aristocracia de nuevo cuño tratará de adquirir prestigio, de asemejarse a la nobleza de linaje a toda costa, para lo cual es imprescindible la adopción de sus formas y usos sociales. Con tal fin, y como muestra de su nuevo rango, abren también sus puertas a la distinguida sociedad, floreciendo en el Madrid romántico los salones de Cambronero, Villavicencio, Mariategui, Gayangos, Vallarino, Aristizábal, Elhuyar, González Arnao, por citar los más sobresalientes, a los que acuden las figuras más notables del mundo artístico e intelectual e, incluso, hasta miembros de la familia real. En palabras de Robert Marrast, "se advierte que en las tertulias de café o de salón, así como en los bailes de máscaras y en las reuniones mundanas, políticas o literarias en general, se produce una ósmosis entre la nobleza tradicional, que ha sobrevivido a las crisis anteriores, y la clase media, de la que algunos miembros están en el candelero gracias a los derechos adquiridos por el dinero o la fama. Se van instaurando paulatinamente nuevas costumbres" 22 .

En aquellas veladas, claros émulos de las aristocráticas, se charlaba, se jugaba a los naipes u otros pasatiempos de mesa, se declamaban poemas y fragmentos de piezas teatrales, se bailaba y se interpretaba música (de manos de aficionados, generalmente, aunque en ocasiones tomaba parte algún artista o compositor profesional, así como profesores de música). Algunos encuentros tenían carácter ocasional, con motivo de ciertas efemérides (santos, natalicios, etc.) o para recibir pomposamente a renombradas figuras del mundo político o artístico. Otros, sin embargo, se celebraban con periodicidad. Su actividad se afianzará en los años sesenta, generalizándose las veladas y conciertos en residencias de políticos, diplomáticos, abogados, militares de rango, médicos y otras profesiones liberales.

Durante el Sexenio, a pesar del languidecimiento que se aprecia en la vida de salón con respecto a los años isabelinos, menos propiciada ahora por una coyuntura socio-política transida de inestabilidad, son relevantes, no obstante, las residencias de ciertos burgueses acaudalados - e importantes hombres de la política- que se codean con la aristocracia, como son los casos del empresario José de Salamanca, el general Serrano, los Buschenthal o los Baüer. Son igualmente notables los pertenecientes a familias acomodadas tales como Bengoechea, Piquer, Mendizábal o Álvarez, cuya tónica general continúa en años posteriores. Ejemplo de ellos lo constituye la reseña periodística recogida a continuación:

"Entre esas reuniones de la buena sociedad de Madrid á las que la música imprime un carácter de gusto y de grata, honesta y amena distracción, debemos citar la última reunion tenida en casa de los Sres.

23. Revista y Gaceta Musical, año II, n. ${ }^{o}$ 3. Madrid (20-I-1868), p. 15. 
de Álvarez, en la que las señoritas de Güell y de Foxá dieron pruebas de poseer cualidades muy distinguidas para el canto. En dicha reunion mostraron tambien sus excelentes facultades artísticas los Sres. Cortés y Valvoni, y el señor Casella se hizo oir en el violoncello con su maestria acostumbrada. El señor Moderati fue el que dirigió el concierto, y las personas invitadas salieron todas en estremo complacidas y satisfechas del buen tacto y delicadeza con que los señores de Alvarez saben disponer y organizar tan bellas reuniones" 23 .

A su vez, la pequeña burguesía se siente igualmente atraída por la moda de los salones. En realidad -y asumiendo nuevamente a una visión retrospectiva de las cosas-, la costumbre de la tertulia nocturna de carácter íntimo, tras la cena y en torno al brasero, en ocasiones con algunos amigos de la casa, constituía ya una práctica cotidiana en las familias de clase media a mediados de siglo, incluso en las de condición más humilde. Era una forma habitual de disipación durante las primeras horas de la noche -a falta de las distracciones de la vida moderna-, momentos en los que se charlaba, se leía en voz alta y, si la ocasión lo disponía, se hacía música. El compositor Ruperto Chapí relata precisamente en uno de sus escritos cómo eran aquellas reuniones familiares durante los años de su infancia, a finales de los cincuenta:

"Mi padre iba poco a poco animándose, y ya, en las noches de invierno, apenas concluida la cena, un chiquillo cogía la luz, el otro, el jarro de agua, otro el brasero, otro la tarima y mientras el padre cerraba las puertas, nosotros, con una algazara que me da envidia recordar, nos encaminábamos escaleras arriba y tomábamos por asalto una pequeña salita en la que cada cual se acomodaba lo mejor que podía junto al brasero, reservando el sitio al padre. La hermana mayor (...), se ponía a trabajar en sus labores para remediar lo mucho que nosotros como chiquillos destrozábamos. Apenas mi padre llegaba, disponía lo que tocaba hacer aquella noche. Las más, se leía en alta voz, en lo que alternábamos los tres hermanos. Allí se leía de todo. Historias, novelas, viajes, dramas, y, en fin, cuanto pudieran dar de sí nuestra pequeña biblioteca y la del maestro mío (...). Si alguna noche venía a cuento, mi padre tomaba la palabra y nos refería episodios de sus buenos tiempos (...). De cuando en cuando, y refiriendo todos los detalles, cogía la guitarra y nos cantaba alguna canción de aquéllas con que se obsequiaban mutuamente negros y blancos, según que los unos subían o bajaban (...). Otras noches se cantaba a coro.

En otros tiempos, mi padre y una porción de amigos, que algunas veces acudían en número considerable, no sé de dónde procuraron unas composiciones a voces solas, sencillas, pero de un carácter grandísimo, con palabras en castellano que se referían a la muerte y pasión (...). Estos motetes eran los que en familia cantábamos, bajo la dirección de mi padre que nos ensayaba, guitarra en mano y con una paciencia inagotable" 24 .

Junto a estos testimonios de factura sencilla, familiar y desenfadada, se dan otras veladas de mayores pretensiones - habilitando para la ocasión todos los espacios disponibles en sus hogares, tanto para dar cabida a la tertulia como para componer pequeños teatros domésticos-, tratando de remedar las prácticas de las clases pudientes, aunque con las limitaciones que su menor capacidad económica les impone. En aquellas salas se disponían modestos grupos de contertulios que, en sabrosa plática, juegos de mesa e interpretaciones musicales, llenaban las horas de solaz.

24. IBERni, Luis G., Ruperto Chapí. Memorias y escritos. Madrid, ICCMU, 1995, pp. 39-40.

25. “Crónica nacional”. La Iberia Musical, año I, n. ${ }^{\circ}$ 2. Madrid (16-I-1842), p. 7. 
Asimismo son reseñables las veladas musicales que renombrados compositores organizaban en sus casas, como Baltasar Saldoni, Santiago Masarnau, Joaquín Espín y Guillén o los Sobejano, recogidas en la prensa musical:

"En la mañana del 6 del corriente hemos tenido el gusto de asistir á un concierto preparado por el Sr. Saldoni, autor de Ipermestra y Cleonice; componiase de piezas escojidas (sic) de dichas óperas, y alguna del Sr. Carnicer, la sociedad era poca por la estrechez del local, pero lucida y elegante.

En esta sociedad de amantes sinceros de la prosperidad y gloria de las artes, reinó un espíritu puro y entusiasta español; las piezas fueron ejecutadas por los discípulos de este maestro y en lo general observamos muy buenas disposiciones: para el canto notándose la voz de tiple, de buena calidad de la señorita F... y la gracia en la manera de decir, de la señorita G...El maestro debe seguramente estar muy satisfecho, del justo aprecio que todos los señores de la sociedad demostraron, manifestándole lo satisfechos que estaban, de que sus tareas, lleven por objeto, presentar todos los adelantos posibles en el arte"25.

El repertorio en aquellas reuniones privadas no era sustancialmente diferente al que gustaba de escucharse en las sociedades artísticas a la sazón, puesto que el público era el mismo. Ópera italiana, adaptada para las circunstancias, copaba los programas. Junto a ella, aunque en proporción considerablemente menor, piezas para piano de carácter virtuosístico y canciones españolas:

"Madrid.- El sábado 28 de enero tuvimos el gusto de asistir al concierto que bajo la direccion de nuestro consocio D. Florencio Lahoz, se celebró en casa del señor brigadier D. Ignacio Lopez Pinto. La funcion se inauguró con una fantasia para piano, arreglada á cuatro manos sobre motivos de la Lucía por el mismo Sr. Lahoz, y ejecutada por él y por la señorita de Guitarte, siendo la primera vez que esta mostraba su habilidad artística en una reunion, circunstancia que le valió merecidos aplausos, tanto por esto, como por la soltura y brillantez con que supo ejecutar la parte que le tocaba en la bella composición de su compañero. Siguió á continuación el aria del Belisario cantada por el Sr. Sínico, del cual es escusado (sic) decir que la desempeñaria perfectamente. El jovencito D. Rafael Ferraz sorprendió después á aquella reunion, tocando en el piano unas variaciones de Herz sobre un tema de la ópera Ana Bolena (...). Las señoritas Gonzalez y Codorniu de Polin cantaron á continuación un duo de Juan de Calais, desplegando en él las eminentes dotes artísticas que las adornan; á lo cual siguió un duo de piano y flauta compuesto sobre motivos de los Puritanos, y ejecutado con el éxito mas brillante por la distinguida pianista señorita Martin y por el eminente flautista nuestro dignísimo compatriota el Sr. Rivas (...). Al aria del Pirata, muy bien ejecutada por el Sr. Sínico, siguiéronse después la de las Prisiones de Edimburgo por la señorita Gonzalez, y otra (cuya ópera no recordamos) por la señorita Codorniu de Polin, en las cuales volvieron á redoblarse los aplausos del auditorio, no menos que en la cancion de los Toros del Puerto (...). El concierto concluyó muy avanzada la noche con unas variaciones de flauta sobre motivos de la Sonámbula por el Sr. Rivas (...)"26.

Es curioso que el italianismo filarmónico y la galofilia cultural imperantes dejasen sitio, aunque pequeño, para el gusto por lo propio, manifestado en aires nacionales interpretados al piano o en canciones españolas. Aunque parezca contradictorio, ambas realidades, extranjerismo y españolismo, conviven en la sensibilidad del público. Por un lado, la apertura hacia Europa que nuestro país experimenta

26. “Crónica nacional”. El Anfión Matritense (periódico filarmónico-poético de la Asociación Musical), año I, n. ${ }^{\circ}$ 5. Madrid (5-II-1843), p. 39.

27. Sopeña, Federico, Historia de la Música Española Contemporánea. Edición consultada: Madrid, Rialp, 1976, p. 19. 
en los años treinta y cuarenta le lleva a tomar conciencia del atraso cultural en el que había permanecido inmerso con respecto a nuestros vecinos, a querer "ponerse al día" y a la altura de los demás, sobre de todo de Francia. Ello conlleva la adopción de usos foráneos en detrimento de los españoles, por los que se siente cierto desdén. La ópera italiana fue, musicalmente hablando, la asimilación primordial del patrimonio extranjero. Federico Sopeña, al reflexionar sobre nuestro siglo XIX, se lamentaba de la pasión por el italianismo en los aficionados, que casi no dejaba lugar para otras músicas. "Sólo hay, decía, una recepción preocupada de estar al día: la de la ópera italiana (...). La minoría de aristócratas riquísimos y cortesanos se contentan con la ópera como espectáculo, mucho más si pensamos que ésa era la música que quería Isabel II"27. Y, como la burguesía emula a la nobleza, ese furor se propaga entre la clase media. Exponente del dominio italiano es el Teatro Real, inaugurado en 1850 como auténtico baluarte de este género.

En contrapartida, no deja de sentirse aprecio por las costumbres nacionales, por lo nuestro, potenciado por el pensamiento romántico -ligado al pintoresquismo hispánico, por entonces de moda en Francia- que penetra en nuestro país, así como por cierta restauración del casticismo aristocrático dieciochesco. Ese populismo españolista se hizo notar de un modo especial durante los años de Isabel II, cuando "a pesar de la admiración de la aristocracia por la ópera italiana, aquel glamour españolista fomentado por la apodada reina castiza y su corte de aristócratas motivó un renovado gusto por las canciones españolas -sobre todo aquellas más picarescas y divertidas, que se prolonga en los años sesenta (...). En efecto, fue durante el reinado isabelino cuando mayor éxito alcanzaron las canciones españolas y andaluzas de Iradier, Soriano, Manuel Sanz, Oudrid y otros autores de menor relieve, como ingrediente lúdico y festivo, secundadas por popurris de aires nacionales para piano y habaneras, en alarde de exotismo criollo" 28 .

Aparte de la música vocal procedente del mundo operístico, la melodía con acompañamiento de piano constituyó uno de los puntales del repertorio de salón durante todo el XIX. Alcanzado el último tercio del siglo, las características de aquél no variarán sustancialmente con respecto a lo estilado en los años isabelinos. A lo dicho hasta ahora hay que añadir el auge de la interpretación vocal a partir de textos franceses e italianos, en detrimento de los escritos en lengua española. Rendidos ante los imperativos de la moda, que estimaba de mejor gusto todo lo que venía de fuera, fueron numerosos los compositores españoles que condescendieron a musicalizar poemas de escritores galos e italianos: Marcial del Adalid, José Inzenga, Joaquín Espín y Guillén, Felipe Pedrell, Emilio Arrieta, Gabriel Rodríguez, Pedro Tintorer y muchos otros recurrieron a la pluma de Hugo, Gautier, Musset, Lamartine y Blanchecotte, los más socorridos en el área francesa, así como a Metastasio, Cataldi, Bignoti, Curti, Badioli, Graciano o Leopardi en la esfera italiana. En ocasiones, las pocas canciones con texto en español halladas en las colecciones de la época aparecen con su traducción al italiano. Esta predilección por cantar en lengua extranjera significó un obstáculo para la proyección de la canción lírica en castellano -lo que también ha sido denominado lied hispano, extrapolando el término del contexto alemán-, al margen de las piezas españolas y andaluzas que sí lograron hacerse un hueco en el repertorio de salón, aunque exiguo en comparación con otros géneros.

28. Alonso, C., La Canción Lírica Española..., p. 218.

29. Nombela, J., Impresiones y recuerdos..., p. 202. 
Entre éstos figuran, sin duda, la música de cámara y la sinfónica, así como la producción pianística de los compositores germanos, a la que los melómanos españoles de la época aluden frecuentemente como música de estilo puro y clásico. Tal género se vio relegado a un plano muy secundario en el repertorio de los salones durante la etapa isabelina. De ello da testimonio Julio Nombela al rememorar sus andanzas juveniles en los años cincuenta, cuando frecuentaba las casas de sus amistades, en su mayoría familias de la clase media:

"Los secretos que puede revelar (el piano) no preocupan a su propietario, la música es un ruido más o menos agradable para él, y si un amigo aficionado le visita, no tiene inconveniente en que toque el piano a su sabor ni en dejarle a solas con el complaciente instrumento. Si sus ocupaciones le obligan a alejarse, se marcha; si se queda y el pianista toca algún aire popular: una jota, una polka, una habanera, el dúo de una ópera muy oída o la canción picaresca de una zarzuela, disfruta a su manera y hasta le ruega que repita. Si el virtuoso, que en este caso sigue siéndolo en el genuino sentido de la palabra, se mete en honduras e interpreta la música sublime de Mozart, de Beethoven, de Chopin o de Schumann; si, soñador, arranca al piano modulaciones que revelan el estado de su ánimo, el propietario del instrumento se aburre, pretexta cualesquiera para alejarse, piensa que aquellas melodías armonizadas por el genio, por la imaginación y por el sentimiento son pura y simplemente lo que se llama, no sé por qué, música celestial, y lo único que siente es que se rompa alguna cuerda del piano o que desafine"29.

A raíz de esta lectura podría deducirse que la música de cámara no "cala", por así decir, en el público español. No obstante, en los últimos años se detecta un interés creciente en algunos círculos, impulsado por la Sociedad de Cuartetos (nacida en 1863) y la Sociedad de Conciertos (1866). La prensa musical de finales de los sesenta recoge las lamentaciones de ciertos filarmónicos que denuncian la preponderancia de la ópera y la música de baile en las reuniones de sociedad tanto como en los teatros, en detrimento del género instrumental de los grandes compositores alemanes. En 1868, la Revista y Gaceta Musical de Madrid recoge una acerada crítica del repertorio para piano en boga a la sazón -erigido instrumento protagonista en las moradas de la clase media y alta españolas-, ya sea como método pedagógico o para ser interpretado en público, nutrido a base de óperas italianas, melodías vocales y danzas, con escasa presencia de las sublimes obras que aquellos maestros compusieron para tal instrumento. Todo ello está muy vinculado al papel de la música y del intérprete en la vida de salón. La intención del firmante es denunciar la inconveniencia de tal repertorio para la formación de nuestros pianistas así como para la educación del gusto del público, revelando al mismo tiempo una reacción -aún lenta e incipiente -por parte de aficionados y profesionales a favor de la música clásica:

"La influencia que sobre el mecanismo de un instrumento tiene el género especial de música que se haya empleado para su estudio es de tal naturaleza, que ella por sí sola hace á veces que el instrumentista llegue á ser mas o menos diestro ó hábil, según la clase de música de que se haya servido para llegar á adquirir el completo dominio de su instrumento.- Muchos en quienes domina la afición por la música teatral procuran después de terminados sus ejercicios, y aun alternando con estos mismos, tocar mucha música perteneciente á aquellas óperas que sean mas de su gusto ó que hayan sido mas aplaudidas y gustadas por el público.- De aquí el que en determinados casos, el neófito pianista no piense en otra

30. "Del género de música que mejor se aviene con el estudio del piano". Revista y Gaceta Musical, año II, n. ${ }^{\circ}$ 19. Madrid (11-V-1868), p. 81. 
cosa mas desde que comienza sus estudios preliminares, sino en poder tocar algun dia una gran pieza de ópera, que lo haga brillar en un salón ó tertulia de confianza (...).

La música de baile entre aquellos que practican el instrumento como mero pasatiempo y fútil distracción, la de ópera entre los que han llegado á un cierto grado de dominio, y el canto y acompañamiento entre los que profesan ó sienten dentro de sí mismos cierto gusto y aficion por saborear á su placer todos los efectos de la música, son las bases sobre que descansa generalmente la práctica y estudio del piano.

Hasta ahora los mismos profesores, puede decirse, que habian contribuido en mas de un caso á esta mala direccion dada á la enseñanza del piano; pero de algun tiempo á esta parte se observa una saludable reaccion, operada a favor de los buenos ejercicios y del buen gusto que los mismos profesores procuran inculcar en sus discípulos, haciéndoles estudiar y comprender bajo todos sus puntos de vista la buena música, ó sea la música de estilo puro y clásico.

La música clásica adquiere, pues, cada dia mayor auge é importancia entre nosotros, y esto no ha podido por menos que influir bastante en la enseñanza de un instrumento, cuyo mecanismo se presta tanto á la traducción exacta de esas obras magistrales que nos han legado los buenos clásicos alemanes" ${ }^{30}$.

En este punto cabría apuntarse, aunque huelgue ya decirlo, el protagonismo indiscutible adquirido por el piano con respecto al resto de los instrumentos. De obligada presencia en todo salón, en toda reunión que se precie - no es infrecuente el caso de familias que, en momentos de precariedad económica, se resignan a pasar "estrecheces" pero no a desprenderse del piano ni de otras piezas del mobiliario que decora la sala donde se reciben las visitas, tal y como relata Galdós en Miau- se convierte asimismo en elemento en torno al cual se concentra la vida familiar durante ciertas horas del día:

"El piano es sin duda el instrumento destinado á acrecentar aún mas los goces y satisfacciones que proporciona la vida del hogar doméstico. -Este instrumento, tan sério y brillante en un salón de concierto, y bajo los dedos de un buen concertista, es al mismo tiempo el mas alegre, el mas risueño, y el mas simpático en las reuniones íntimas de familia (...). El piano en una casa anima le home, como dicen los ingleses, infunde la alegría y la espansion (sic)de ánimo, y hace olvidar las labores y las faenas del dia. Tan pronto como se ha terminado la comida, uno de los miembros de la familia, el mas jóven tal vez, pasea sus dedos sobre el teclado, haciendo oir algun motivo favorito, ó alguna nueva partición (...).

Después de la primera pieza viene otra, y después otra, y las horas se pasan de este modo sin sentir, oyendo en la mas grata intimidad un concierto modesto y sencillo, pero lleno de gran atractivo (...).

El piano ha triunfado muchas veces del café, del teatro, de las tertulias y del juego, consecuencia casi inevitable de ciertas clases de reuniones. Pero es, sobre todo, fuera de las grandes poblaciones, en los pequeños pueblos ó en el campo, en donde el piano ejerce toda su benéfica influencia. ¿Qué hacer durante esas largas noches de invierno, en las que, cada uno encerrado en su casa, no tiene otros medios de distracción que los que él mismo se proporcione?- Hacer música, como dicen los franceses (...). Por esta razon el piano ha sido siempre el instrumento favorito de los compositores y de toda clase de aficionados á música, así como ha llegado á ser hoy el mueble indispensable en todas las casas, y particularmente en las moradas ó quintas de recreo, donde se vive apartado de los grandes centros y de las grandes ciudades" 31 .

No en vano, la intensificación de la actividad socio-musical en torno a dicho instrumento deriva en un desarrollo si precedentes de la fabricación de pianos en nuestro país. Las fuentes de la época

31. "El piano en familia”. Revista y Gaceta musical. Año II, n. ${ }^{\circ}$ 23, Madrid (8-VI-1868), p. 100. 
revelan que la calidad en la manufactura pianística de los constructores españoles se coloca, durante la segunda mitad de siglo, a la altura de las naciones más avanzadas del momento, recibiendo, incluso, algunas recompensas y distinciones en exposiciones universales. Las casas Romero y Eslava se sitúan a la cabeza en este sector de la producción, seguidas por otras firmas como Montano, Ferrer, Samaniego, Salazar o Casimiro Martín, la mayoría de las cuales era igualmente distribuidora de música impresa.

La difusión del repertorio interpretado en las veladas, tanto privadas como de sociedades artísticas, fue impulsada por la enorme proyección de la edición musical a partir de los años treinta y cuarenta. Proliferan los "álbumes de salón", nutridos a base de piezas vocales -arias italianas, canciones españolas, romanzas francesas, arreglos de zarzuelas- y música para piano, fundamentalmente (a veces para otros instrumentos, como guitarra, violín, flauta). Estas colecciones de "música de salón", como entonces se estila denominarla, podían ser adquiridas en los numerosos almacenes de música que se inauguran en Madrid, siguiendo las huellas de los de Lodre y Carrafa. Celsa Alonso señala "el almacén de Sebastián de Iradier (1850-1863), el de Conde-Martín Salazar (activo entre 1849-1872), el de Casimiro Martín Bessières (1851-1873), el de Nicolás Toledo (1856-1884), el de Bonifacio Sanmartín Eslava (1856-1881) y el de Antonio Romero y Andía (funda su almacén en 1854 y su editorial en 1856, vigentes hasta 1898)"32. A ello hay que añadir las partituras editadas en los suplementos musicales que, semanal o quincenalmente, eran publicados en revistas filarmónicas como La Iberia Musical, La España Artística, La Gaceta Musical de Madrid, por citar algunas, e incluso en álbumes que otras revistas de carácter ecléctico, como el Semanario Pintoresco Español o El Laberinto, hacían llegar por entregas, bien gratuitamente o a módico precio (sin entrar en ello ahora, señalemos simplemente que la propagación de música en medios periodísticos ha de ser enmarcada en el fenómeno de la literatura por entregas que, con carácter general, se pone de moda a partir de los años treinta, posibilitada por la flexibilización del reglamento sobre libertad de expresión tras la muerte de Fernando VII). Sirva de muestra la siguiente información aportada por El Anfión Matritense en su primer número:

"Los señores suscritores (sic) reciben todos los meses dos entregas de música, compuestas de cuatro planchas cada una, quedando á su arbitrio suscribirse á cualquiera de las cuatro secciones siguientes. Primera: De obras elementales, principiando por el método de solfeo. Segunda: De armonía, contrapunto y composición, dando principio por el tratado de armonía. Tercera: De música recreativa, comprensiva de las piezas mas escogidas de piano y canto. Y cuarta: De música fácil al alcance de todos los aficionados, en la cual se comprende toda clase de canciones españolas, de carácter sério y jocoso, con acompañamiento de piano y guitarra, walses para piano solo y guitarra sola; rigodones, mazourkas, galops y demas composiciones ligeras para dichos instrumentos y para flauta, pudiendo optar por cualquiera de los tres instrumentos indicados, manifestándolo al tiempo de suscribirse. Mas adelante se hará estensiva esta última seccion á todos los demas instrumentos" 33 .

O la que a continuación se ofrece de La Iberia Musical:

32. Alonso, C., La canción lírica..., p. 214.

33. El Anfión Matritense (periódico filarmónico-poético de la Asociación Musical), año I, n. ${ }^{\circ}$ 1. Madrid (3-I-1843), p. 1. 
"Biblioteca continua de música. Los señores suscritores de la IBERIA recibirán (gratis) con cada número una composición de canto español é italiano (con acompañamiento de piano), ó de piano solo, de lo mas selecto y original.

La Redaccion cuenta al efecto con la cooperación de los mas célebres compositores de España y el estranjero" 34 .

La lectura de algunas reseñas aparecidas en prensa especializada de la época, como la anterior de El Anfión Matritense (Crónica nacional, 5-II-1843), pueden dar la impresión de que el diletantismo imperante en las veladas no era óbice para el disfrute del público. A juzgar por los elogios tributados a los intérpretes se deduciría que éstos eran de alto nivel. Sin embargo, otros testimonios de la época constatan una realidad bien distinta. La crítica redactada por J. Espín y Guillén al respecto, sumamente mordaz pero rebosante de humor, publicada por La Iberia Musical y Literaria en 1843 y distribuida en varios números de la publicación, pone de manifiesto que el talento de los aficionados -inficionados, como los llama satíricamente el articulista- dejaba habitualmente mucho que desear, prodigándose en desatinadas interpretaciones que herían la sensibilidad de los auténticos músicos profesionales:

"Hay personas que creen haber nacido dotados de jénio (sic) y talento superior para todas las ciencias, para todos los artes; y si se trata de la música, ¡oh! Soy músico desde que mamaba; suelen decir unos: y otros; desde la edad de tres años; leo yo lo mismo un papel de música, al revés que al derecho. Que hay disposiciones músicas, no hay que dudarlo; pero que estas disposiciones se aprovechen con utilidad del que la tiene y del arte, es cosa bastante difícil. Por ejemplo, ¿cuántos cantantes ó instrumentistas de salon, y aun de teatros, vemos que poseen una magnífica voz, y en vez de cantar, aullan? Cuantos rascadores de violin, ó tocadores de cornetin á piston no inundan las sociedades y destrozan impíamente el tímpano del que por una educación mal entendida, tiene que permanecer sentado forzosamente en una silla, hasta que el inspirado y atroz instrumentista concluye de ejecutar unas variaciones mas largas que una cuaresma?

-Tendrá V. la amabilidad de asistir al gran concierto vocal é instrumental, que doy mañana en mis salones. La marquesa de...Señor don F. de P. señora, hermanitos, é hijos...A las ocho en punto de la noche.

Pues señor no hay remedio, al recibir tal billete de convite, tiene V. que ponerse de punta en blanco, cojer (sic) la mujer, los hijos, los hermanos, y algunos amiguitos que se pirran por los conciertos de aficionados (y yo los llamaria de inficionados) (...).

Comencé á oir composiciones orijinales de los maestros directores; es decir, zurcidos malditísimamente cosidos, de todos los autores, y de todas las óperas modernas. Hoí cantar con tal entusiasmo, que, las arañas, lámparas, candelabros, techo y suelo, temblaban al oir tales bramidos. Una señorita tocó al piano unas variaciones, compuestas por uno de los que se llaman compositores, y que no se le podia sufrir aquella noche de orgullosillo que estaba, que baste decir que la mano derecha tocaba en sol, y la izquierda acompañaba en la menor; por supuesto, tocó con muchísima gracia, meneaba mucho la cabeza, miraba al cielo en los pasos de inspiración, ... y cuando acabó (que yo creí que no concluia de tocar en toda la noche), los aplausos llegaron al último cielo. Comenzaron á afinar, el vizconde y el marquesito, y el pobre piano recojió el fruto de la destreza de ambos aficionados, pues los candelabros besaron forzosamente las cuerdas del piano, dejándolo mas destemplado que campana del lugar (...).

Filarmónicos: huid siempre del que os diga, yo compongo de aficion; canto de aficion; toco de aficion; soy aficionado; tengo mas jénio que Rossini! Esto es muy bueno para los papás y mamás; pero para una sociedad, ¡qué horror!...iqué tormento!...iqué destrozo!"35.

34. La Iberia Musical. Gaceta de Teatros, año V, n. ${ }^{\circ} 18$. Madrid (10-V-1846), p. 141.

35. Espín y GuILlÉN, Joaquín, "Los músicos pintados por sí mismos o sea fisiología del músico. De las pretensiones músicas. Lo difícil que es el conocerse a sí mismo”. La Iberia Musical y Literaria, año II, n. ${ }^{\circ}$ 39. Madrid (8-VIII-1843), p. $322-323$. 
Del artículo anterior se deduce que "el mal del diletantismo" afecta a los tres sectores que toman parte en la escena. Por un lado, los intérpretes, cuya deficiente formación musical no deja de ser un mero complemento para lucirse en sociedad y henchir de orgullo a sus progenitores, pero que, a la hora de la verdad, "destrozan" lo que tocan. Para subsanar tal defecto, en los años cuarenta se crean varios establecimientos de enseñanza destinados a esos aficionados, como el Museo Musical y el Gimnasio Musical de Madrid, con el fin de proporcionarles los conocimientos necesarios para la correcta interpretación del repertorio. Por otra parte, el diletantismo se ceba asimismo en los compositores, quienes, o bien no tienen capacidad o formación para la tarea, o bien han de amoldar sus obras a los futuros intérpretes, de ahí la mala calidad del repertorio. Por último hay que mencionar el público, carente de la instrucción necesaria para valorar lo que se le ofrece.

Veamos un último testimonio del perjuicio que la introducción del aficionado en sociedad hizo derivar en el arte músico y en las propias reuniones, aparecido en la prensa especializada de mediados de siglo. En esta ocasión, sin embargo, hemos de subrayar la buena intención del articulista, quien, tratando de dar una visión justa de las cosas y lejos de anatemizar la figura del diletante en términos generales, se cuida mucho de medir a todos los filarmónicos por el mismo rasero, ponderando la benéfica influencia de algunos de ellos. Se trata, en definitiva, de una apreciación ostensiblemente más benévola que las recogidas hasta el momento, por cuanto que difiere entre aficionados beneficiosos y perjudiciales:

"Se llaman generalmente diletantes todas las personas de cualquiera clase ó posición que sean, que buscan en el estudio de la música, no un medio de subsistencia pero sí de distracción y placer. Esta epíteto de diletante deberia indudablemente tener sus restricciones, pues no todos los que se ocupan de la música por placer ó diversión merecen ser calificados de esta manera, asi como tampoco todos las músicos merecen ser llamados artistas.

Existe una clase de aficionados sin talento, sin vocacion, sin ardor y sin celo, que no ocupándose de música mas que por vanidad, se proponen solamente llegar á cierto grado de agilidad necesaria, suficiente para poderse poner en evidencia en las sociedades. Lejos de ser provechosos al arte, estos aficionados le perjudican por el contrario, á causa de sus pretensiones, y sobre todo, por los fallos que tan audazmente emiten sobre todo lo tocante al arte; sucediendo á veces que su posición social impone como una autoridad á los artistas, que por desgracia dependen de ellos. Estas personas, según nuestra manera de ver, no se las deberia llamar diletantes. Mas hay otras que consagran á la música sus horas de recreo y de placer, por afecto, por amor ó por entusiasmo; las cuales, sin estar precisamente ligadas á los intereses del arte, toman parte sin embargo en todo lo que en él sucede, que se asocian para ocuparse de él con mas resultados, y que se esfuerzan en instruirse por medio de la conversación ó de la lectura, á fin de ir penetrando cada vez mas en la intimidad del arte: estos aficionados merecen cierta consideración y estímulo, y á ellos solamente daremos al título de diletantes" 36 .

Dejando a un lado el aspecto musical, hemos de decir que, si bien la adopción de gustos foráneos se dirigió masivamente hacia el italianismo operístico en el terreno filarmónico, los usos socio-culturales centraron su atención en el mundo francés, algo que venía sucediendo desde los últimos años de Fernando VII. París se convierte en el punto de referencia. La cultura francesa penetra en los salo-

36. “Artistas y diletantes”. Gaceta Musical de Madrid, año I, n. ${ }^{\circ} 22,1-V I I-1855$, p. 172. 
nes -y en otros espacios de la vida pública- como modelo de buen gusto. Todo lo francés se mira con buenos ojos. Indumentaria, lecturas, términos e incluso gestos franceses son objeto de una emulación sin precedentes en tiempos de Isabel II. Esa imitación desaforada ya es observada a principios de los cuarenta por Theophile Gautier, quien, tras mencionar diversos aspectos de las tertulias que había conocido durante su viaje por España, hace un comentario altamente significativo de la adoración manifestada en los españoles por su país: "para colmo del desencanto, todo el mundo habla francés perfectamente, y gracias a algunos elegantes que pasan los inviernos en París y van a la Ópera, entre bastidores, son conocidos perfectamente en Madrid los personajes de segunda fila más ignorados" 37 . Incluso se aplica un término galo a las reuniones de sociedad, hecho que inspiró a Antonio Flores, célebre costumbrista y acérrimo defensor de lo español, más de una sátira: “y no tengo inconveniente alguno en que vengas a cualquiera de esas diversiones que cuando no había palabra que les sirviera en el Diccionario de la Lengua las llamaban saraos, y ahora que la teníamos hecha las conocemos con el nombre de soirées" 38 .

En estrecha vinculación con lo francés hallamos toda una serie de convencionalismos que se instalan en los salones madrileños, los cuales, como ya había lamentado Mesonero, asfixiaban las reuniones "de buen tono". Fernández de Córdova, quien gustaba de presentarse en las veladas de la aristocracia, nos transmite a la perfección, y a modo de elogio, el "empaque" que envolvía la alta sociedad de 1836:

"Lo que allí reinaba, constituyendo el lado más característico y la fisonomía más sobresaliente de la sociedad, era lo que, a falta quizá de nombre más adecuado, llamaré el gran tono, es decir, la distinción de las maneras, la cortesía exquisita llevada al último extremo del refinamiento; la educación, en suma. Las damas eran tratadas y atendidas con exageradísimas demostraciones de respeto; la consideración y el miramiento hacia las personas de posición y de edad eran por todos guardadas, y llegábase hasta hacer un especial estudio para aprender la manera de penetrar en un salón, saludar, sentarse, etc." ${ }^{39}$.

Efectivamente, por aquellos años se podían adquirir en la librería de Cuesta las obras más significativas para aprender a conducirse en las veladas de la sociedad distinguida. Tal es el caso del Manual completo de urbanidad, cortesía y buen tono ó el hombre fino al gusto del dia, con las reglas, aplicaciones y ejemplos del arte de presentarse y conducirse en toda clase de reuniones, visitas etc, en el que se enseña la etiqueta y ceremonial que la sensatez y la costumbre han establecido; con la guia del tocador y un tratado de arte cisoria o del Manual de señoritas, ambos traducidos del francés, naturalmente, y catalogados ya en el apéndice al Manual de Madrid que "El Curioso Parlante" reeditó en 1835.

En aquellos salones de buen tono, tanto particulares como de sociedades artísticas, era frecuente hallar, junto a los convencionalismos de procedimientos y costumbres, los de caracteres. F. Díaz-Plaja ha esbozado, no sin una buena dosis de sátira y con mucho humor, ciertos personajes de nuestra España romántica, incondicionales de las reuniones de sociedad que se desvivían por hacerse notar entre la

37. GAUTIER, Theophile, Viaje por España. París, Charpentier, 1859. Edición consultada: Barcelona, Taifa, 1985, pp. 109-110.

38. Flores, Antonio, Ayer, Hoy y Mañana ó La fe, el vapor y la electricidad. Cuadros sociales de 1800, 1850 y 1889. Barcelona, Montaner y Simón, 1893. Edición consultada: La sociedad de 1850, Ayer, Hoy y Mañana. Madrid, Alianza, 1968.

39. Fernández de CóRdova, F., Mis memorias..., p. 300. 
gente distinguida. No podía faltar el lechuguino, ya caricaturizado por Larra a finales de los años veinte, cuyos rasgos predominantes Díaz-Plaja sintetiza en tres: tener dinero, despreciar lo español y emplear el mayor número posible de palabras extranjeras. "En este sentido, añade, el lechuguino es un legítimo heredero del petimetre (siglo XVIII), incluso en su afectación al hablar y moverse para huir de lo celtíbero, que considera duro y áspero" 40 . Otro tipo habitual en los salones es el calavera de buen tono, a quien el autor estima "el más simpático de los calaveras, y a la gente le encanta. Habla bien, dirige la sociedad, inicia el aplauso en la ópera, monta a caballo, habla francés, inglés e italiano. Lee a Paul de Kock, a Walter Scott, D’Alincourt, Cooper, Voltaire, Pigault-Lebrun; y esto y bailar bien le convierten en el rey de las reuniones. De vez en cuando tiene un escándalo ligero con una casada, que no produzca demasiado trastorno, pero que sirva para mantener su fama. Si es necesario, se bate también, pero procura hacerlo a primera sangre, y casi siempre sus desafíos se terminan con un almuerzo amistoso". En realidad, el calavera de buen tono no es más que uno en la variada tipología que Larra ideó para caracterizar los personajes aludidos con la denominación genérica de calaveras, entre los que se hallan el calavera silvestre, el lampiño, el temerón, el langosta, el falso y el viejo calavera, que gustaban de trastornar con sus fanfarronadas los más variados ambientes del Madrid decimonónico, ya sea aristocráticos o populares. Tampoco hemos de olvidar a los pollos, de género masculino o femenino, en los que se dan algunas características de los anteriores personajes. Sus rasgos fundamentales son la juventud y una insoportable petulancia. A ello se añade la pasmosa ignorancia que demuestran a cada paso, como constataba Narciso Serra en 1851 a través de su personaje de Don Luis Escamilla: "los pollos son, corregida y aumentada, la edición del currutaco, del petrimetre; una cáfila imberbe que, sin saber, por ejemplo, quién fue Wamba, censuran obras ajenas, fastidian a las muchachas y no saben hacer más que el nudo de la corbata" ${ }^{41}$.

La vida socio-musical madrileña no se agota en estos espacios de índole aristocrático-burguesa. Al entretenimiento hallado en salones privados y sociedades artístico-recreativas hay que sumar el que proporcionan los numerosos bailes de máscaras -de enorme éxito desde los últimos tiempos de la Ominosa Década, cuando fueron nuevamente permitidos tras años de férrea prohibición por ser considerados ocasión propicia para desórdenes y fechorías-:

"Tiempo hacía ya que el Gobierno permitía los bailes de máscaras, absolutamente prohibidos durante la última época absolutista de don Fernando VII, cual si estos placeres, de todo punto inocentes, en cuanto a sus relaciones con la seguridad del Estado, pudiesen comprometer el orden y la paz. El público madrileño y todas las clases de la sociedad, contrariadas por aquellas prohibiciones, de la que es, sin duda, una costumbre y una afición tradicional en España, demostraron en esta época de más conveniente tolerancia verdadero furor por los bailes de máscaras" 42 .

Organizados en cafés, teatros, residencias particulares y sociedades, los había para todas las clases sociales. La aristocracia solía darse cita en el gran salón de Santa Catalina, al menos hasta 1837,

40. DíAz-Plaja, Fernando, La vida cotidiana en la España romántica. Madrid, EDAF, 1993, p. 178. p. 19.

41. SERRA, Narciso, Un huésped del otro mundo (comedia en un acto y en verso). Madrid, Imp. de José Rodríguez, 1868,

42. Fernández de CóRdova, F., Mis memorias..., p. 302. 
cuando la apertura del Liceo atrajo la clientela al palacio de Villahermosa. Aquellos bailes solían organizarse de la siguiente manera: la primera parte, que discurría con disfraz y careta, daba pie a la desinhibición en la conducta de los participantes, a la exteriorización de sentimientos habitualmente reprimidos, puesto que, aparentemente, no había peligro de que su identificación les deparase consecuencias desagradables. De ella nos dice el Marqués de Mendigorría que constituía "una verdadera locura, un frenesí de alegría y de animación; veían los hombres descubiertos los secretos e intrigas que suponían mejor guardados; encontraban allí ocasión propicia para ardientes declaraciones y para conocer su buena o mala fortuna, y las mujeres podían decir sin esfuerzo lo que sólo en la vida común les es lícito demostrar con manifestaciones tímidas e indirectas". No obstante, parece ser que las cosas no permanecían en el anonimato deseable, ya que, según añade el marqués, ésta "comenzaba en el momento de desaparecer las caretas, tenía otro carácter de gravedad y comedimientos, mas subsistían y hacíanse notar las consecuencias de la primera". No es de extrañar que los bailes de máscaras gozasen de enorme éxito, teniendo en cuenta que proporcionaron aventuras curiosísimas y chistosas escenas, junto a más de un disgusto y desavenencia (léase rupturas matrimoniales e, incluso, escapadas del hogar paterno), comidilla de la sociedad.

La clase media se veía en la Fontana de Oro y en el Salón de Oriente. Finalmente, el Marqués de Mendigorría recuerda "unos de candil y de gente de rompe y rasga en las calles de la Parada y de Luzón, donde se reunían las chulas y manolas más típicas y hermosas de la ciudad, y a los que de cuando en cuando asistíamos los militares, seguros de hallar en ellos bellezas del pueblo".

Los bailes fueron exponente de la influencia extranjera -sobre todo francesa, inglesa y alemana-, materializada en valses, rigodones, polkas, mazurcas, redowas y otras danzas foráneas que desplazaron a los aires nacionales en las preferencias del público, especialmente entre las clases acomodadas. El languidecimiento de los bailes autóctonos fue observado por Th. Gautier como fenómeno generalizado en la Península, más admirado por los extranjeros que llegaban a nuestro país incitados por el pintoresquismo hispánico que por los propios lugareños, según lo anotó en sus apuntes de viaje:

"En cuanto al baile nacional, es inexistente. En Burgos, y en Vitoria y en Valladolid nos habían dicho que las buenas bailarinas estaban en Madrid; en Madrid nos dijeron que las verdaderas bailarinas de cachucha sólo se podían hallar en Andalucía, en Sevilla. Ya veremos; pero mucho nos tememos que, para esto de los bailes españoles, habrá que retornar a Fanny Elssler y a las hermanas Noblet. Dolores Serral, que tanta expectación causó en París, en donde nosotros fuimos los primeros en hacer notar la audacia apasionada, la ligereza voluptuosa y la gracia petulante que caracterizan sus bailes, se ha presentado varias veces en el teatro de Madrid sin producir el más mínimo efecto; hasta tal punto se ha perdido en España el sentimiento y el aprecio de los bailes nacionales. Cuando empiezan a bailar la jota aragonesa o el bolero, la gente distinguida se levanta y se marcha: sólo se quedan los extranjeros y la gente del pueblo, en la que el instinto poético es más difícil de borrar"43.

En realidad, todos los espacios en los que se ofrecían bailes, como teatros -en cuyos repertorios eran incluidos, junto con óperas, dramas, comedias y sainetes- y veladas privadas, acusaron esa progresiva sustitución de lo propio por lo foráneo, como prueba de refinamiento o de haber adquirido el

43. GAUTIER, Th., Viaje por España..., pp. 110-111. 
"buen gusto" tan predicado en los círculos burgueses. F. Díaz-Plaja, en su ameno recorrido por la vida social de la España isabelina, ha recogido la queja que el célebre costumbrista de la época Martínez Villegas emitió en 1845 al respecto:

"Confieso mi pecado; el rigodón será muy bueno, pero no me gusta; la mazurca será invención de un genio de la danza, pero no me peta; el galop, el britano, las italianas, la misma polka universalmente celebrada, serán bailes divinos, pero no me llaman. Lo que yo deseo, cuando acabo de ver una comedia, no es ver salir a un hombre muy serio a hacer juegos de pies con el baile inglés ni la gavota, sino oír aquel repiqueteo de castañuelas que me levanta de la luneta preludiando las inexplicables gracias del fandango. Algunos dirán que tengo mal gusto, que no pertenezco al gran tono; qué sé ya lo que dirán. Pero yo me río de todo..." ${ }^{4}$.

Con el paso del tiempo, la creciente atracción suscitada por los bailes durante el período de Isabel II los convierte en espacios privilegiados para el encuentro social, a menudo verdadero objetivo de los asistentes. En los Salones Orientales y en el de Capellanes, los más famosos a mediados de siglo, vamos a encontrarnos los mismos personajes que desfilan por las tertulias. El baile -y por tanto la música- es una excusa que propicia la ocasión de trabar relaciones convenientes. Es, en cierto modo, un trasunto de lo que sucede en las reuniones privadas.

Tras los críticos años del Sexenio, la restauración política implicará una reactivación de las costumbres sociales perjudicadas por la inestabilidad política de aquel corto período. Al igual que en tiempos de Isabel, teatros, cafés, sociedades, embajadas y residencias particulares abren sus puertas a los bailes de máscaras, dominados por las danzas extranjeras.

Sobre la práctica de los bailes aristocráticos durante los últimos lustros del siglo hallamos información en las memorias del Marqués de Lema, quien gustaba de concurrirlos en sus años de mocedad y soltería:

"Grandes bailes había también por aquellos tiempos. La sociedad tenía entonces una animación que todavía parecía escasa a los viejos que ponderaban las fiestas de sus mocedades; yo sólo puedo, naturalmente, hablar de las mías. Ninguna casa superó en ellos a la de Fernán-Núñez; hablo de los grandes bailes en que no sólo se veía a lo más distinguido de la sociedad, sino a hombres públicos, artistas, cuanto brillaba en el país (...).

El primer gran baile a que asistí fue uno que dejó grata recordación, celebrado en 1884, en el palacio de Cervellón, donde lució una preciosa comparsa de la Comedia Italiana, en la que figuraron las mujeres más bellas de entonces, y no fueron pocas, según pueden dar testimonio fotografías que todavía se conservan, y las de otro baile poco después verificado en casa de los marqueses de Viana, que era la misma de su sobrino, al que dejaron el título y ha conocido la actual generación desempeñando sucesivamente el segundo y primer cargo palatino. Lo notable de esa fiesta fue una tarantela bailada, con pocas diferencias, por los mismos que se lucieron en casa de Fernán Núñez.

Grandes bailes daban también la duquesa de Bailén, en su bello palacio, y el marqués de Cerralbo; y eran el espejo de la distinción, por lo escogido de la concurrencia, los de los marqueses de la Romana y Molíns; y por este motivo y lo lucido y exquisito de la casa y de todos sus accidentes y detalles, los de los condes de Villagonzalo" $"$.

44. Díaz-Plaja, F., La vida cotidiana en la España romántica..., p. 160.

45. Bermúdez de Castro y O'Lawlor, S. (marqués de Lema), Mis recuerdos..., pp. 79-80. 
Existen igualmente otros espacios de sociabilidad informal donde la música adquiere notable presencia, ejerciendo un relevante papel en la vida social de los madrileños: los cafés. No en vano, Emilio Casares ha descrito este ámbito como "uno de los núcleos de actividad musical más importantes de la España romántica y, junto con el salón burgués, el de más destacada actividad, no obstante su carácter marginal. Cuando hablamos de ellos, añade, nos estamos refiriendo a un núcleo central de la música romántica" ${ }^{46}$. Los cafés con música, presentes ya a principios de siglo junto con los que acogían tertulias de escritores y políticos, adquieren gran proyección a partir de los años de las regencias y su acción perdurará a lo largo de todo el XIX e, incluso, hasta bien entrado el XX.

Sin detenernos en ello, recordemos que existió una rica tipología de cafés con música, según la procedencia social y el nivel económico de la clientela, por un lado, y la actividad filarmónica que tuviese lugar en ellos, por otro. Ésta última ha dado lugar a diversas denominaciones, como café concierto, café cantante, café teatro y café lírico ${ }^{47}$.

Siendo habituales las interpretaciones a cargo de piano sólo, en los cafés también hicieron música las agrupaciones instrumentales más variadas, generalmente de cámara, difundiendo un repertorio marcado por el eclecticismo: aires nacionales, arreglos de ópera italiana y de zarzuelas, canciones andaluzas, piezas para piano y música camerística de procedencia centroeuropea. En algunos se dispuso un pequeño teatro donde algunas compañías -denominadas "piquetes"- representaban breves obras dramáticas.

El mérito de aquellos establecimientos está en que no sólo sirvieron para llevar música a todos los sectores de la población -es importante la accesibilidad brindada a los estratos populares, quienes por poco dinero podían gozar de un entretenimiento que les estaba vedado en otros espacios-, sino en que fueron el "salvavidas" de numerosos intérpretes y compositores sin trabajo a consecuencia del proceso desamortizador. Gracias a ellos pudieron sobrevivir muchos artistas en una España carente de la infraestructura musical adecuada para emplearlos, al margen de los teatros y de las sociedades artísticas que los subvinieron. De hecho, la mayoría de las grandes figuras de la música española decimonónica fueron "músicos de café" durante algún tiempo de su vida y allí dieron a conocer las primicias de buena parte de sus composiciones.

46. CASARES, Emilio, "El café concierto en España", en Tiempo y espacio en el arte. Homenaje al profesor Antonio Bonet Correa. Madrid, Universidad Complutense, 1994, pp. 1285-1286. En este pequeño artículo el autor proporciona una nutrida lista de cafés con música que proporcionaron abundante solaz a los ciudadanos en Madrid y Barcelona a lo largo del siglo XIX y comienzos del siguiente, así como de intérpretes y compositores que amenizaron con su música las horas ociosas de la clientela, considerando que ambas urbes aportan la mayor fuente de información para el estudio de este fenómeno. No obstante, la costumbre del café concierto se extendió igualmente a las provincias.

47. CELsa Alonso ha hecho un breve pero enjundioso esbozo de esas tipología en el apartado "Canción lírica, café-cantante y cante flamenco" de su obra La Canción Lírica Española en el siglo XIX, op. cit., pp. 362-368, al cual remitimos. 